$$
\begin{aligned}
& \text { بررسى اثر نانوذرات اكسيد روى سنتز شده به روش شيمى سبز با دنا } \\
& \text { مهيناز جنكى'، آزاده محمدقلى' و عادله ديوسالار' }
\end{aligned}
$$

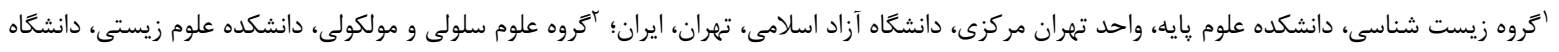

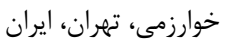

$$
\begin{aligned}
& \text { a.mohammadgholi@yahoo.com مسئول مكاتبات: آزاده محمدقلى ائل }
\end{aligned}
$$

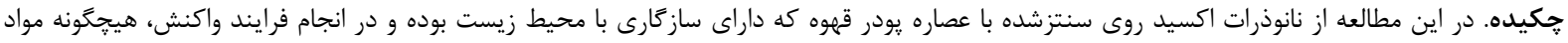

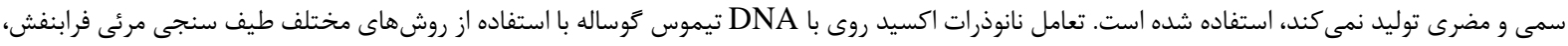

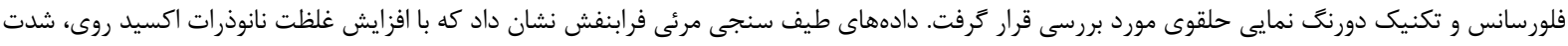

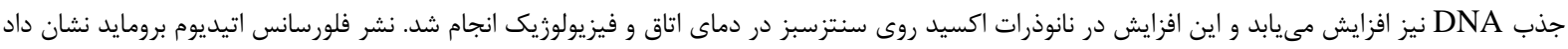

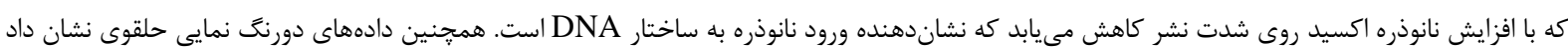

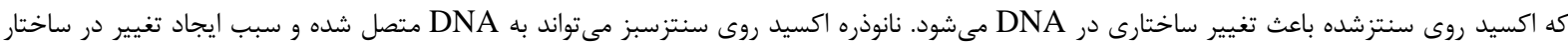

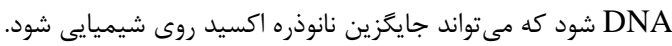$$
\text { وازههاى كليدى. دىاكسىريبونوكئيك اسيد، طيف سنجى مرئى فرابنش ، عصاره يودر قهوه، غده تيموس كوساله، فلورسانس }
$$

\title{
The investigation of the effects of synthesized Zinc oxide nanoparticles on the DNA using green chemistry
}

\author{
Mahnaz Jangi ${ }^{1}$, Azadeh Mohammadgholi ${ }^{1}$ \& Adeleh Divsalar ${ }^{2}$ \\ ${ }^{1}$ Departement of Biology, Faculty of Basic Sciences, Central Tehran Branch, Islamic Azad University, Tehran, Iran; \\ ${ }^{2}$ Department of Cell and Molecular Biology, Faculty of Biological Sciences, Kharazmi University, Tehran, Iran \\ Correspondent author: Azadeh Mohammadgholi, a.mohammadgholi@yahoo.com
}

\begin{abstract}
In this study, the extract of coffee powder was used to synthesize the zinc oxide nanoparticles due to the compatibility of the method with the environment and the absence of any toxic substance as the byproduct of the reaction. Then, the interaction of zinc oxide nanoparticles with calf thymus DNA was investigated by various spectroscopic methods such as UV-Visible, fluorescence and circular dichroism (CD) techniques. UV-Visible data showed that zinc oxide nanoparticles induced denaturation in DNA in a dose-dependent manner at both the room and physiologic temperatures. The results of extrinsic fluorescence emission of ethidium bromide (EB) also showed that the increase of the zinc oxide nanoparticles concentrations led to the decrease of the emission intensity of EB. This may be the consequence of the intercalation of the nanoparticles into the DNA structure. Also, CD data showed that the synthesized zinc oxide caused structural changes in the DNA. According to the results, it can be concluded that zinc oxide nanoparticles can bind with DNA and induce some structural changes in the DNA structure.
\end{abstract}

Keywords. coffee powder extract, calf thymus, deoxyribonucleic acid, fluorescence, Uv-visible

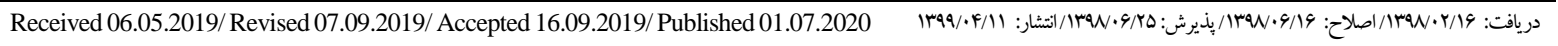


Sangeetha et al., 2011). اهميت مطالعه اثر نانوذرات اكسيد روى سنتزسبز براى درمان بيمارىهاى سرطانى مورد استفاده و

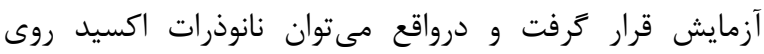
سنتزسبز را براى بهبودى بعضى از بيمارىها استفاده كرد ) Singh جاض الز عار (et al., 2011; Yanget al., 2016; Sun et al., 2005 حاضر از عصاره كياهان مانند عصاره يودر قهوه براى بيوسنتز

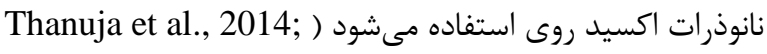

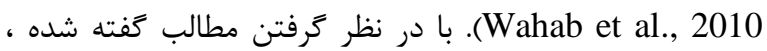

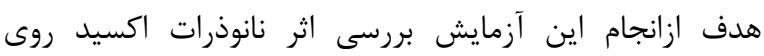
سنتزسبز بر DNA غده تيموس كوساله است. استفاده از غده آندات

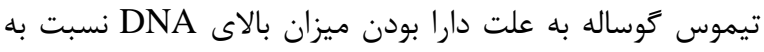

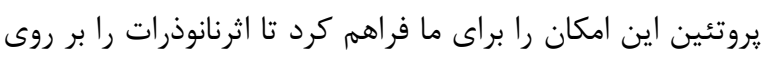

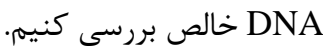

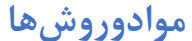

نانوذرات اكسيد روى به صورت آماده از شركت نانو صنع آنتى

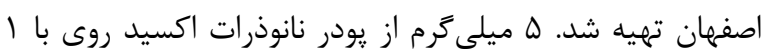

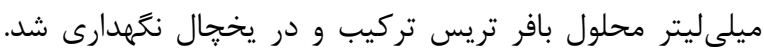

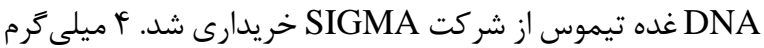

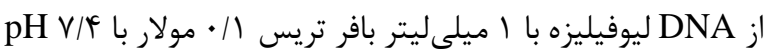

تركيب و در يخجال نكهدارى شد (Stephenson, 2010).

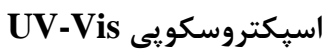
تغييرات طيف جذبى DNA در مقابل اضافه شدن هر سه دقيقه

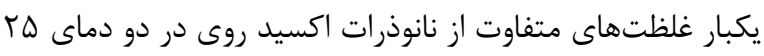

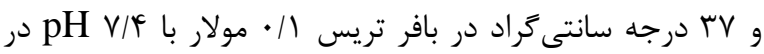

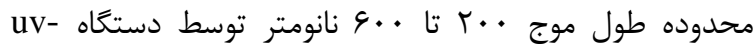

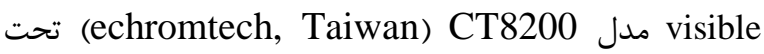
G بر سى قرار كرفت. به منظور ارزيابى بارامترهاى ترموديناميك

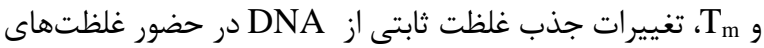

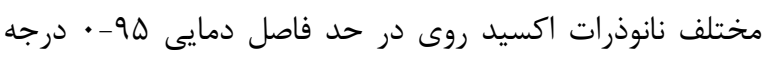
سانتى

(Green et al., 1974)

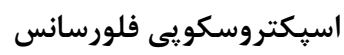

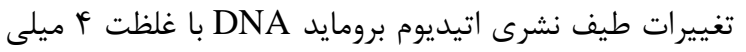

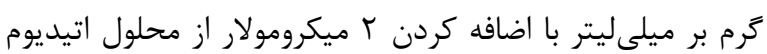

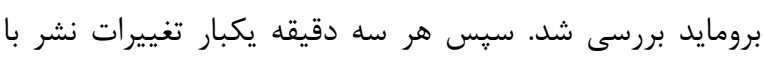
غلظتهاى متفاوت نانو ذرات اكسيد روى در بافر تريس / / • مولار

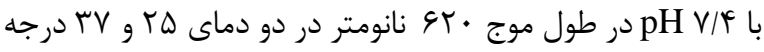
سانتى
مقلهم

نانوذرات در بسيارى از حوزههاى يزوهشى همجون مهرندسى بافت، حس گرهاى زيستى مبتنى بر سلول، ميكروآرايههاى يرتوان

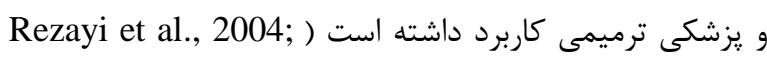
(Ankamwar et al., 2005 فناورى يزشكى مىتوانند براى شناسايى بيمارى و توزيع دارو و همجنين توزيع هورمون در بيمارىهاى مزمن ونقصهاى سيستم

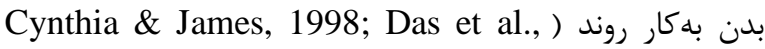
2013). ابزارهاى بسيار ييشرفتهتر، از قبيل نانوروباتها به عنوان

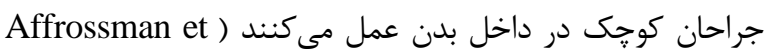

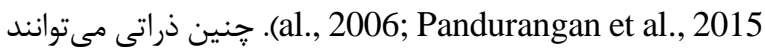
با ورود به داخل سلولها ساختار آسيب ديده را تغيير دهند و

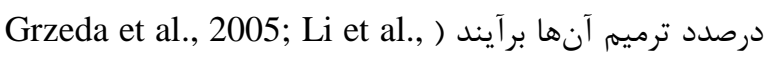
2010). اهميت تركيبات فلزى و نانوذرات در يزشكى و درمان درمان سرطان است (Andrei \& Zhao, 2008). نانوذرات براى انتقال

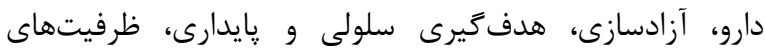

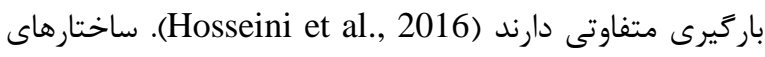
ميكرو و نانو سبب ايجاد تغييرات متعددى همجون هم ترازى،

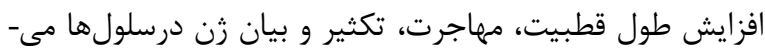

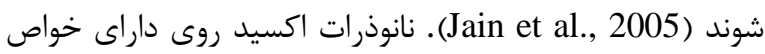
ضدباكتريايى بالا و خواص ضدويروسى بوده و از تكثير ويروس ايدز

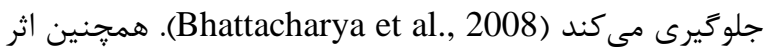
ين نانو ذرات بر ويروس هريس و هياتيت B مشاهده شده است (Karimi et al., 2011). صدماتى مانند سوختخى، بريدگى يوست، جوش، زگيل، بيمارىهاى قارجى و ديخر بيمارىهاى

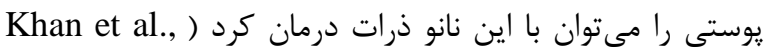

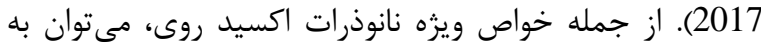
پايدارى شيميايى بالا، ثابت دى الكتريك پايين، فعاليت كاتاليزورى

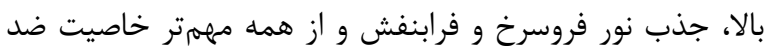
باكترى اشاره كرد (Hudlika et al., 2012). نانو ذرات، حساسيت، سرعت و انعطافيذيرى تستهاى بيولوزيكى را جهت

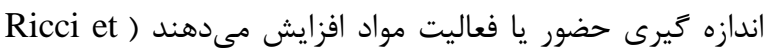
al., 2007 (ازاينرو جايكزينى روشهاى سنتز سبز اكسيد روى در

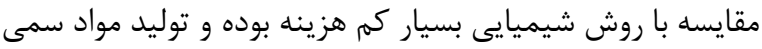

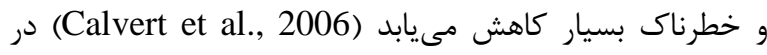
بسيارى از حوزهها از جمله صنايع داروسازى، صنايع بهداشتى و آرايشى، يزشكى، خودروسازى از نانوذرات اكسيد روى سنتز سبز استفاده مىشود (Sharma et al., 2007). هم اكنون سنتئ، برديز نانوذرات اكسيد روى با استفاده از ميكروار كانيسهها، باكترىها،

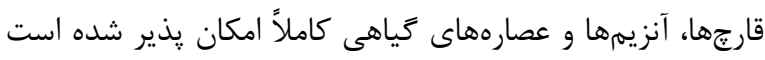


متفاوت از نانوذرات اكسيد روى است. براى نانوذرات اكسيد روى دي

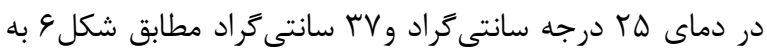

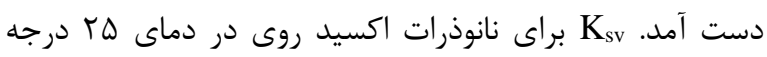
سانتى گراد

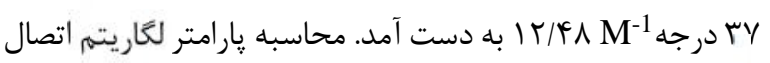

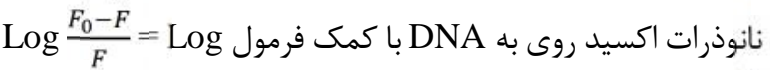
محاسبه شد. KA + n Log $\frac{[Q]}{X}$

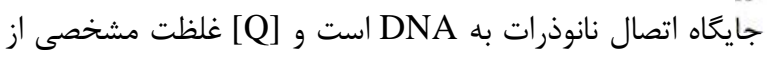

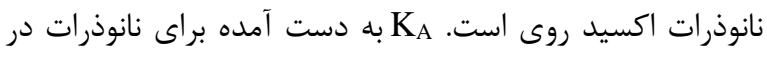

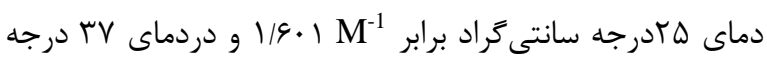

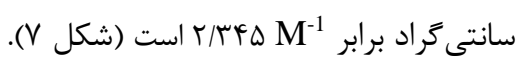
طيفسنجى CD يكى ازروشهاى بسيار مفيد براى تشخيص

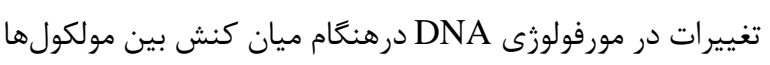

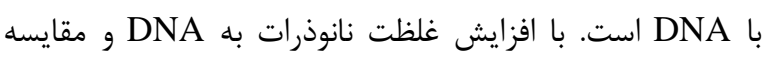

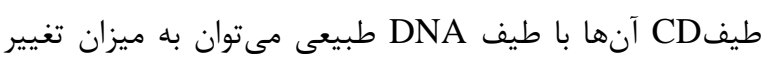

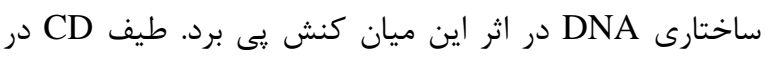

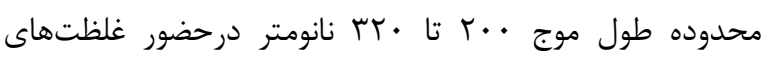

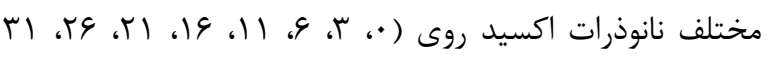

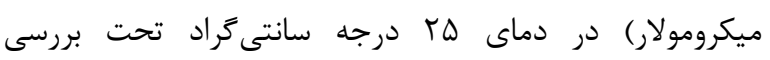

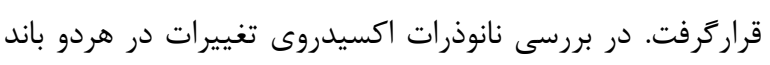

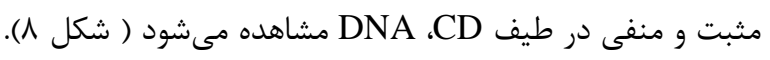

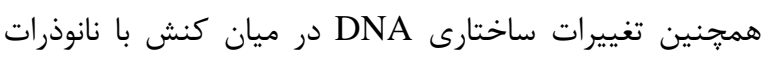

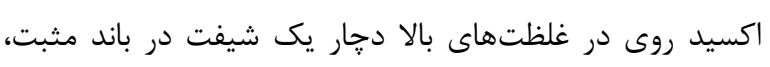
ناحيه مربوط به Stacking بازها مىشود.

بحث

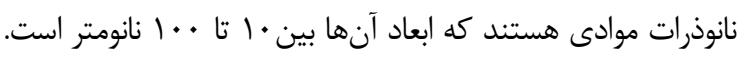

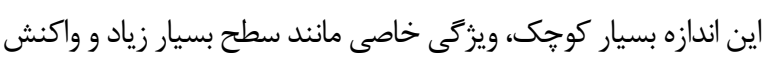

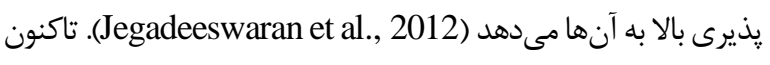

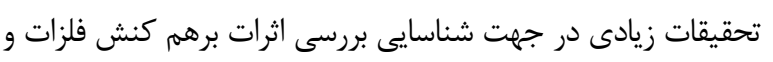

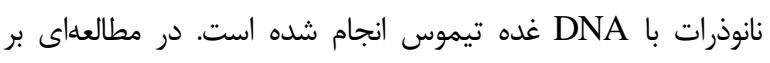

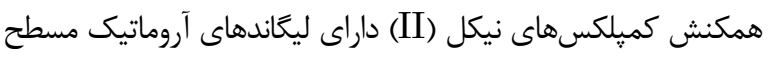
با DNA غده تيموس بررسى شد. اين مطالعه نشان داد كه اين

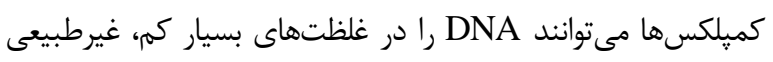
كنند. مطالعه طيف سنجى و ديناميك مولكولى برهمكنش كميلكس

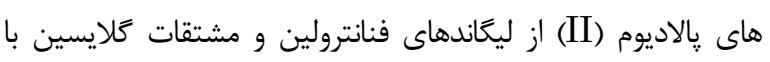
غده تيموس گوساله (CT-DNA) انجام شده است كه نتايج

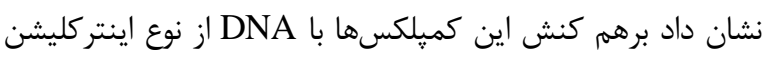

است (Eslami Moghadam et al., 2015).
ثبت شد. در طول انجام آزمايشات از (Agilent, United State) كوت كوارتز با عرض يك سانتىمتر استفاده شد.

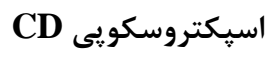

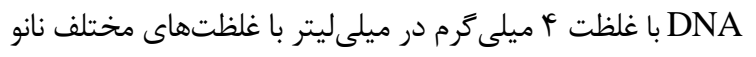

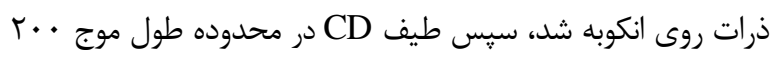

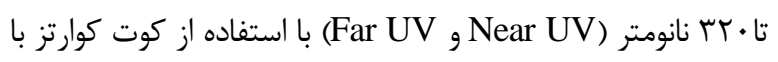

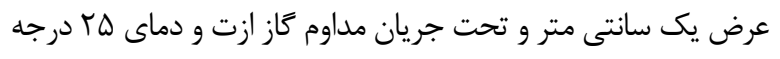
سانتى گر اد با كمك دستخاه 215 AVIV انجام شد.

نتايج نتايج حاصل از طيف سنجى مرئى - فرابفش نشان داد با افزايش

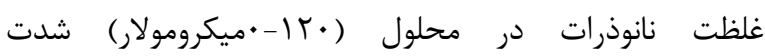
جذب DNA نيز افزايش يافته است (شكل ا). به منظور ارزيابى (نسي

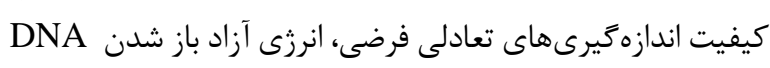
با استفاده ازتحليل (unfolding) H2O $\Delta \mathrm{G}$ سانتى

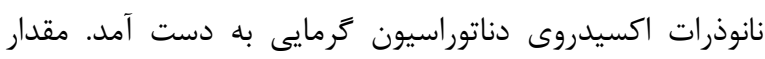

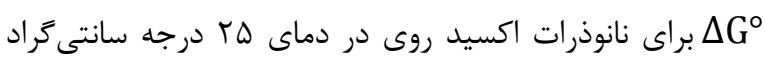
(KJ/mol) (KJ/mol)

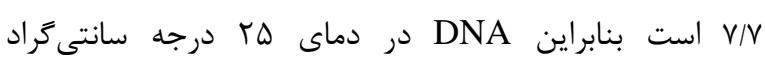
يايدارتراست زيرا

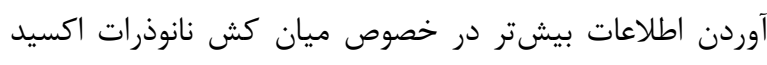

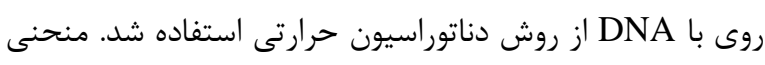

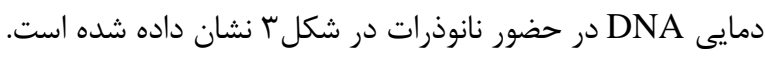

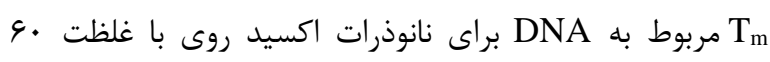

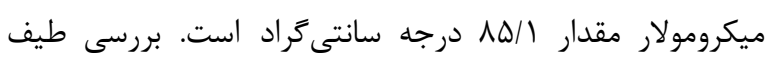

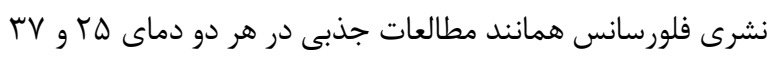
درجه سانتى

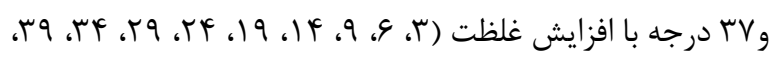

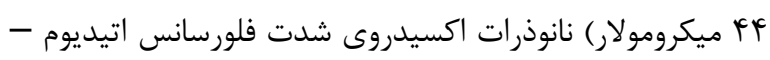

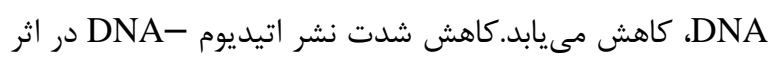

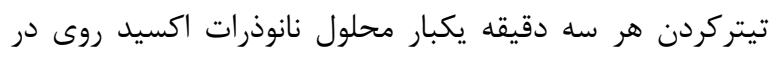

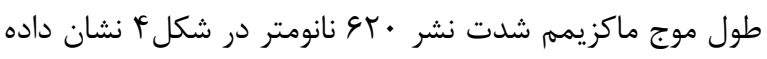

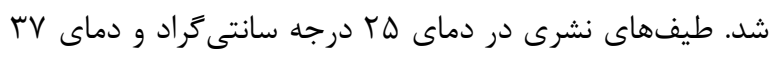

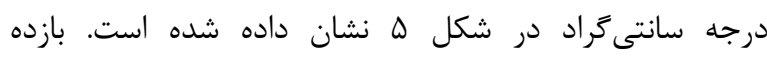

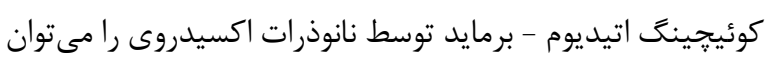
توسط ثابت Stern -Volmer (K

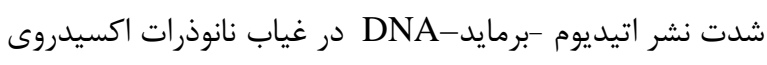

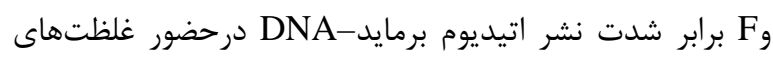




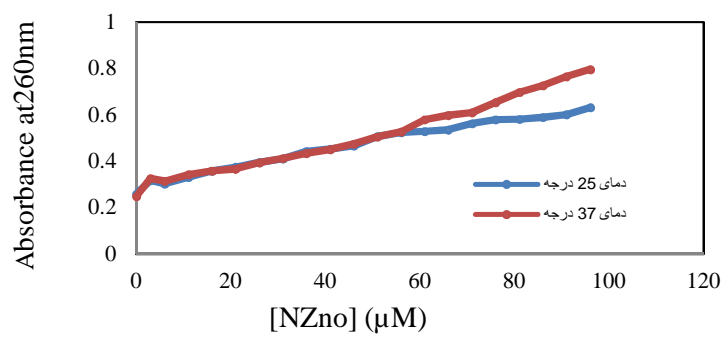

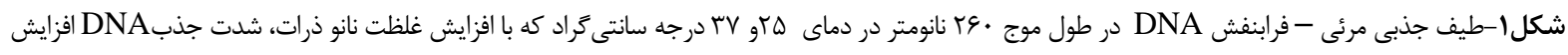

Fig. 1. Visible absorption of DNA at $260 \mathrm{~nm}$ and at 25 and $37^{\circ} \mathrm{C}$, the increase of nano-particle concentration increased the absorption of DNA.

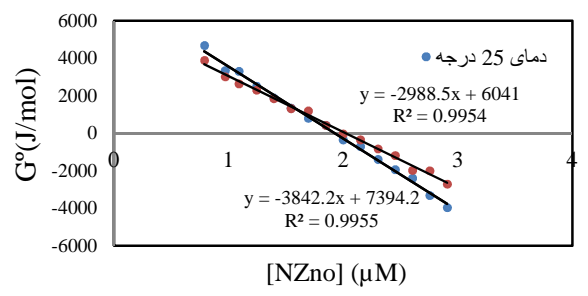

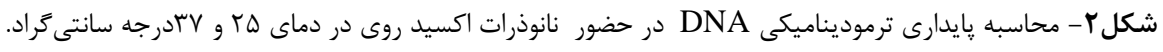

Fig. 2. Calculation of thermodynamic stability of DNA at $25^{\circ} \mathrm{C}$ and $37^{\circ} \mathrm{C}$.

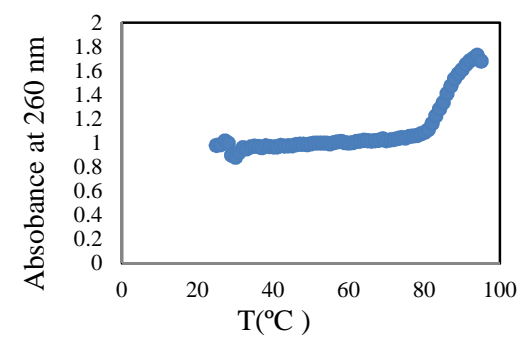

$$
\text { شكل r- دناتوراسيون حرارتى DNA در حضور نانوذرات اكسيد روى. }
$$

Fig. 3. DNA denaturation in the presence of nano-particles.

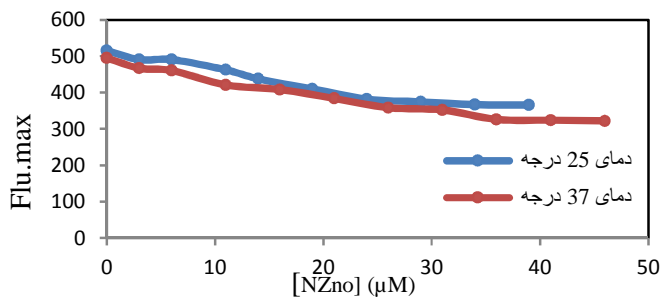

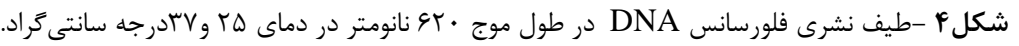

Fig. 4. Fluorescence emission spectra of DNA at $620 \mathrm{~nm}$ at $25^{\circ} \mathrm{C}$ and $37^{\circ} \mathrm{C}$.
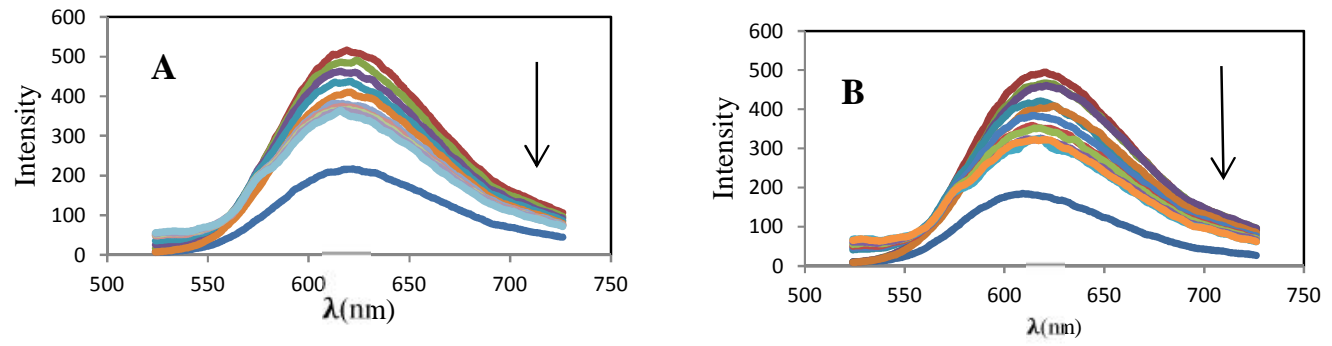

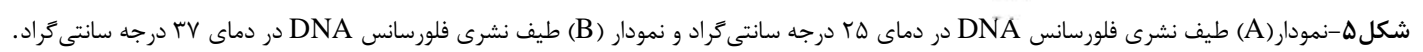

Fig. 5. A. Fluorescence emission spectra of DNA at $25^{\circ} \mathrm{C}$. B. the fluorescence emission spectra of DNA at $37^{\circ} \mathrm{C}$. 


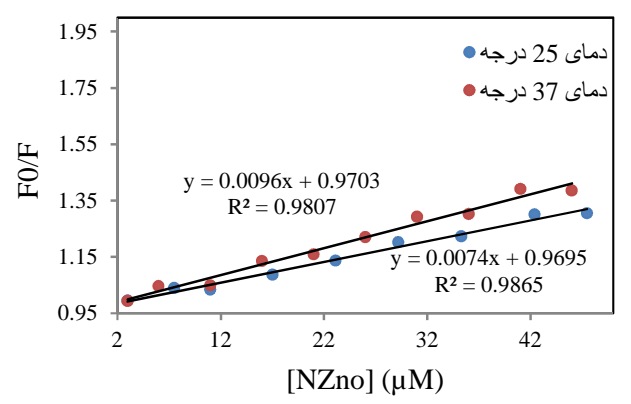

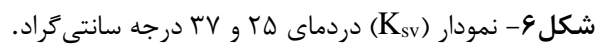

Fig. 6. Ksv graph at 25 and $37^{\circ} \mathrm{C}$.

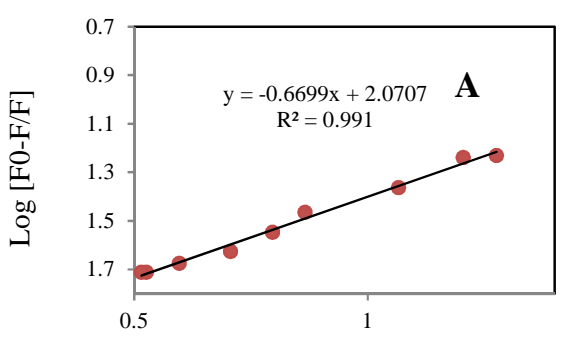

$\log [\mathrm{NZno}]$

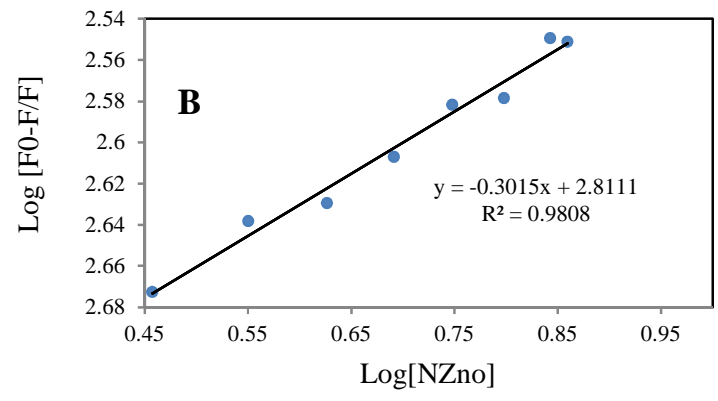

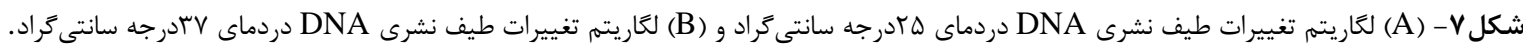

Fig. 7. A. Logarithm of changes in intensity of DNA emission at $25^{\circ} \mathrm{C}$. B. Logarithm of changes in intensity of DNA emission at $37^{\circ} \mathrm{C}$.

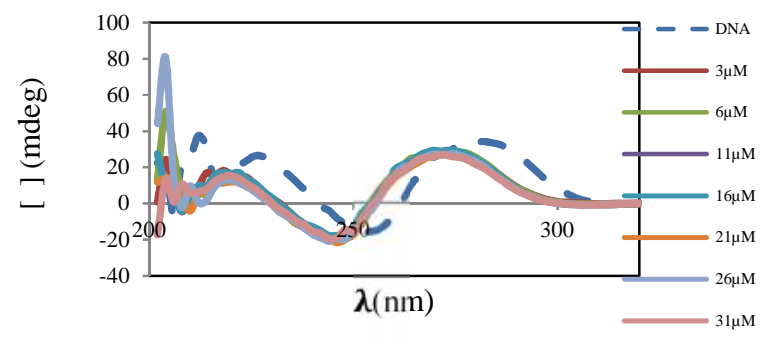

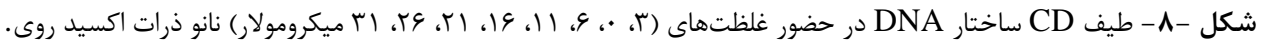

Fig. 8. CD of DNA in the presence of nano-particle $(0,3,6,11,16,21,26,31 \mu \mathrm{M})$.

نانوذرات اكسيد روى سنتزسبز در ماكزيمه طول موج جذبى DNA است كه به تشكيل كميلكس جديدى از مارييج دورشتهاى r منجر مىشود. افزايش شدت جذب در طول موج DNA نانومتر نشان مىدهدكه بين بازهاى آلى DNA و نانى منودرات اكسيدروى سنتزسبز ميانكنش وجود دارد كه اين اتصال به به به به تغييرات دركنفورماسيون DNA منجر مىشود. نتايج بهدستآمده از طيفهاى فلورسانس كاهش زيادى در شدت نشر اتيديوم برمايد DNA با اضافه كردن غلظتهاى مختلف نانوذرات اكسيدروى سنتز سبز نشان مى دهد كه كاهش شدت نشر مى تواند بيانكر رقابت نانوذره اكسيدروى سنتزسبز با اتيديوم برمايد در سئني
علاوه بر اين، بر هم كنش كميلكسهاى پالاديوم (II) با DNA در غلظتها و دماهاى بالاتر بيشتر بود. در نهايت يارامترهاى

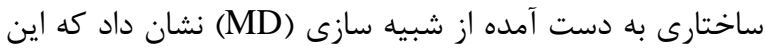

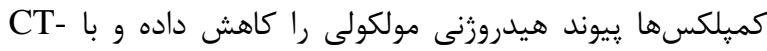
DNA

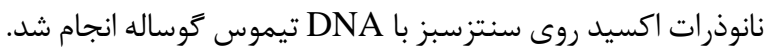
بدين منظور از تكنيك طيف سنجى مرئى - فرابنفش استفاده شده

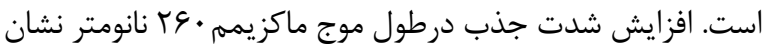

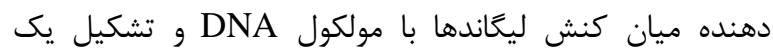
كميلكس جديد با مارييج دورشتهاى DNA است. تغييرات مشاهده شده در طيف جذبى DNA در حضور غلظتهاى متفاوت 
با DNA است زيرا افزايش Tm و پِايدارى، يكى از عوامل پيوند با

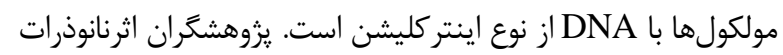

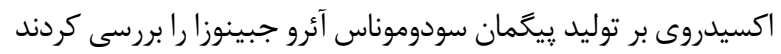

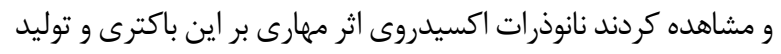

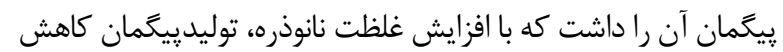
يافت (Nakhaei Moghaddam et al., 2016). بنابراين از نانوذرات

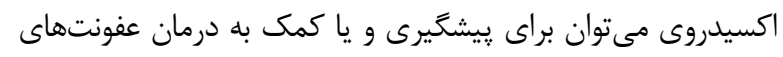

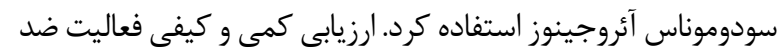

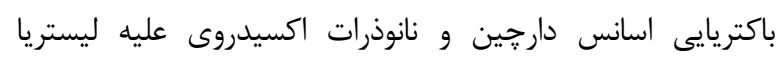
مونوشيتوزنز بررسى شده است (Ojagh et al., 2018) كه اين مطالعه عليه

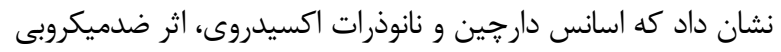

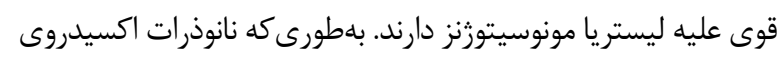

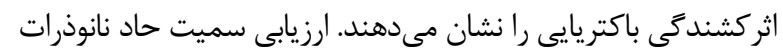

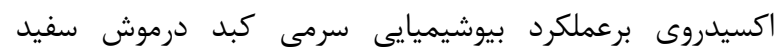

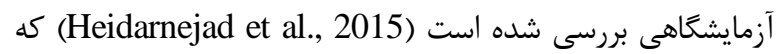

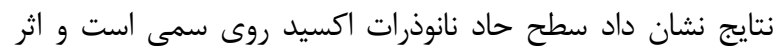

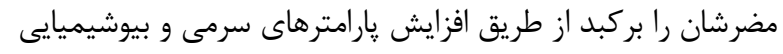

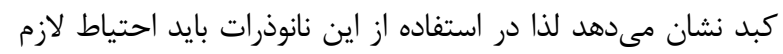

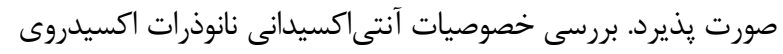

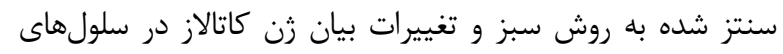
سرطان كبدى انسان (HEP62) بررسى شده است كه اين مطالعه

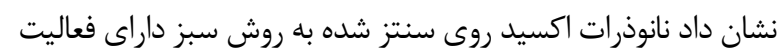

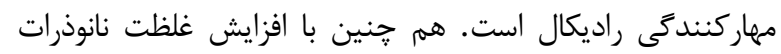

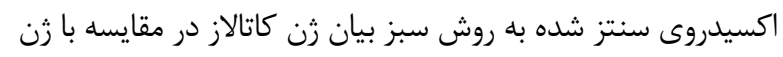

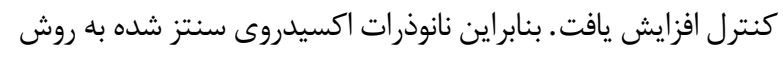

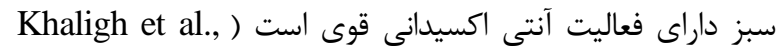

(2016

$$
\text { نتيجه كيرى }
$$

بنابراين طبق نتايج به دست آمده مى توان از نانوذرات اكسيد روى

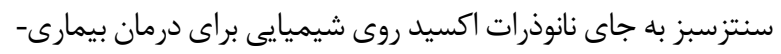

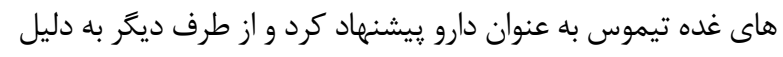

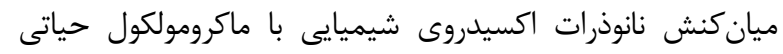
سلول (DNA) بايد به اثرات جانبى ايجاد شده در اثراستفاده روز افزون

$$
\text { آن براى انسان و محيط زيست نيز توجه كرد. }
$$

$$
\text { سياسخَزارى }
$$

از مركز تحقيقاتى بيوشيمى - بيوفيزيك دانشكاه تهران، دانشكاه

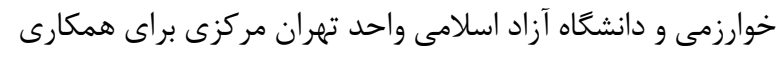
در اين تحقيق قدردانى مىنماييه.
اتصال به DNA باشد. به عبارت ديكر مىتوان نتيجه كرفت كه

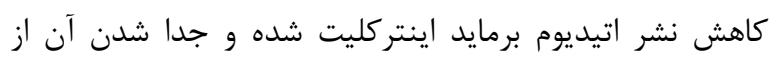

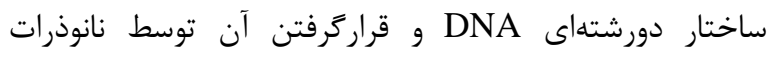
اكسيدروى سنتزسبز است كه سبب فرايند خاموشى فلورسانس

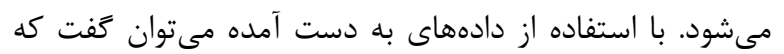

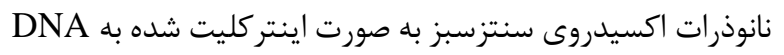

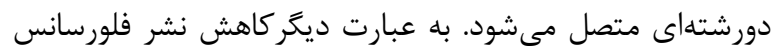

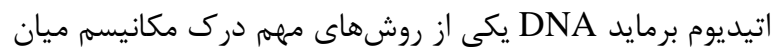

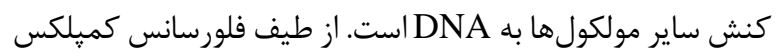

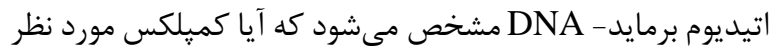

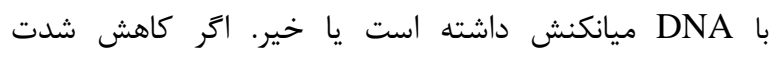

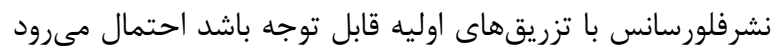

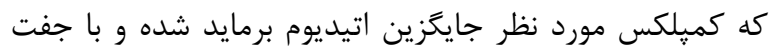

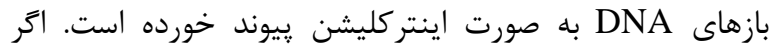

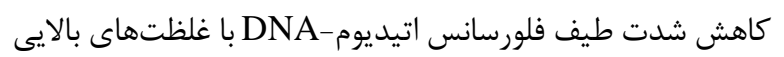

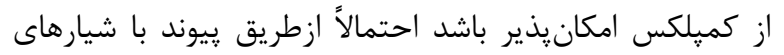

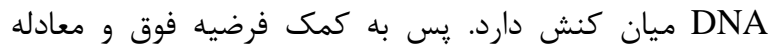
مي توان Stern-volmer اكسيد روى به DNA در نظر كرفت و بدين ترتيب ميزان تمايل

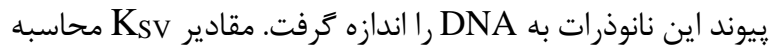

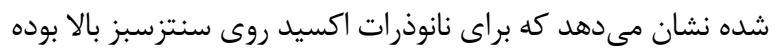

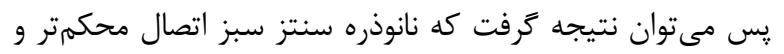

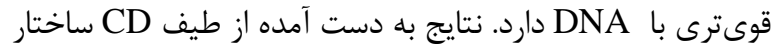

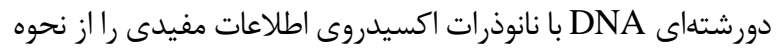

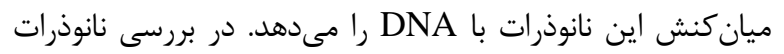

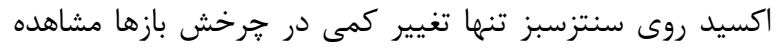

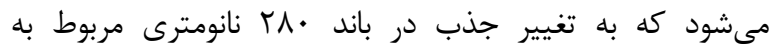

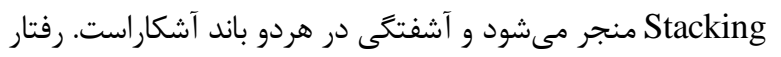
دمايى DNA در حضور كميلكسها مى مئواند اطلاعاتى درباره

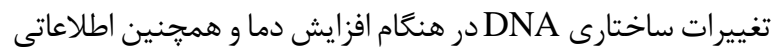

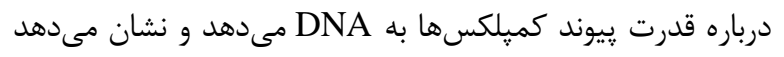

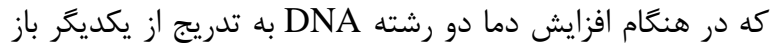

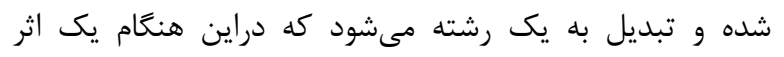

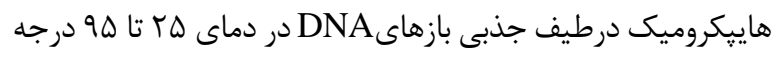

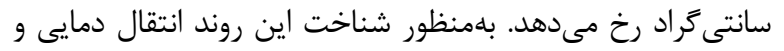

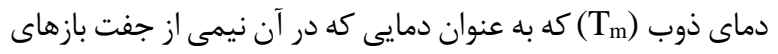

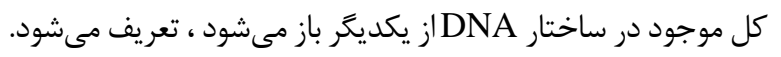

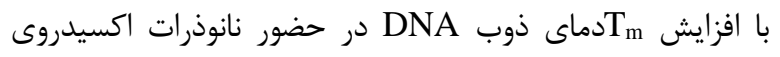

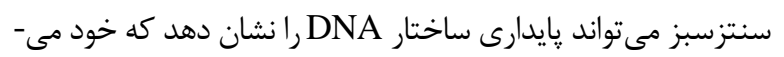
تواند نشاندهنده اثرييوند اينتر كليشن نانوذرات اكسيد روى سنتئرس سينز 


\section{REFERENCES}

Affrossman, S., Agheli, H., Robertson, M. \& Dalby, M. 2006. Osteoprogenitor response to semi-ordered and random nanotopographies. Biomaterials 27: 2980-2987.

Ajloo, D., Eslami Moghadam, M., Ghadimi, K., Ghadamgahi, M., Saboury, A., Divsalar, A., Sheikh Mohammadi, M. \& Yousefi, Kh. 2015. Synthesis, characterization, spectroscopy, cytotoxic activity and molecular dynamic study on the interaction of three palladium complexes of phenanthroline and glycine derivatives with calf thymus DNA. J. Inorganica Chimica Acta 4: 144-160.

Andrei, V. \& Xin Zhao, Z. 2008. Imaging of zinc oxide nanoparticle penetration in human skin in vitro and in vivo. Biomedical 13: 1-9.

Ankamwar, B., Damle, C., Ahmad, A. \& Sastry, M. 2005. Biosynthesis of gold and silver nanoparticles using Emblicaofficinalis fruit extract, their phase transfer and transmetallation in an organic solution. Nanosci. Naonotechnol. 15: 1665-1776.

Bhattacharya, R. \& Mukherjee, P. 2008. Biological properties of naked metal nanoparticles. Adv. Drug Deliv. Rev. 60: 289-306.

Cynthia, B. \& James, M. 1998. Oxidative nucleobase modifications leading to strand scission. Chem. Rev. 98: 1109-1152.

Das, D., Nath, C., Phukon, P. \& Dolui, K. 2013. Synthesis of $\mathrm{ZnO}$ nanoparticles and evaluation of antioxidant and cytotoxic activity colloids surf. Biointerfaces 5: 511-556.

Saboury, A., Mansouri Torshizy, H., Saeedifar, M., Divsalar, A. 2011. Binding studies of a novel antitumor palladium (II) complexes to calf thymus DNA. J. Nucleos. Nucleot. Nucl. Acid 30: 405-422.

Tomaszewska-Grzeda, A., Lojkowski, W., Godlewskib, M., Yatsunenko, S., Drozdowicz-Tomsia, K., Goldys, E.M. \& Phillips, M.R. 2005. Growth and Characterization of $\mathrm{ZnO}$ Nanoparticles. Acta Physica polonica A 108: 897-902.

Greene, R.F. \& Pace, C.N. 1974. Urea and guanidine hydrochloride denaturation of ribonuclease, lysozyme, achymotrypsin, and $\beta$-lactoglobulin. J. Bio. Chem. 249: 5388-5393.

Hosseini, M., Shareghi, B., Saboury, A. \& Davar, F. 2016. Green synthesis of zinc oxide nanoparticles and their effect on the stability and activity of proteinase K. RSC. Adv. 6: 42313-42323.

Hudlikar, M., Joglekar, H., Dhaygude, M. \& Kodam, K. 2012. Latex-mediated synthesis of $\mathrm{ZnS}$ nanoparticles. J. Nanoparticle Res. 14: 855-865.

Heidarnejad, S., Fatahian Dehkordi, R. \& Ameri, A. 2014. $\mathrm{ZnO}$ nanoparticles effects on male rat gonad histology and its effect on blood serum sex factors. J. Shahrekord Univ. Med. Sci. 16: 65-71.

Jain, K. 2005. Nanotechnology in clinical laboratory diagnostics. Clinica Chimica Acta 3: 37-54.

Khan, S., Ansari, A.A., Abdulla,M., Al-Obaid, O., \&Ahmad, R. 2017. In vitro evaluation of cytotoxicity, possible alteration of apoptotic regulatory proteins, and antibacterial activity of synthesized copper oxide nanoparticles. Colloids Surf. B 153: 320-326.
Khaligh, F., Namvar, F. \& Vesal, M. 2016. Evaluation of antioxidant properties of zinc oxide nanoparticles synthesized by green method and catalase gene expression changes in human liver cancer cells (HepG2). Sci. J. Ilam Univ. Med. Sci. 24: 71-82.

Karimi, J., Kazemi, H., Mohsenzadeh, S. \& Safavi, A. 2011. Iosynthesis of gold nanoparticles using dried flowers extract of Achillea wilhemsii plant. J. Nanomater. Biostructures 6: 1011-1017.

Li, J., Guo, D., Wang, X. \& Chen, B. 2010. The photodynamic effect of different size $\mathrm{ZnO}$ nanoparticles on cancer cell proliferation in vitro. Nanoscale Res. Lett. 5: 1063-1071.

Marmur, J. \& Doty, P. 1962. Determination of the base composition of deoxyribonucleic acid from its thermal denaturation temperature. J. Mol. Bio. 5: 109-118.

Nakhaei Moghaddam, M. \& Najafi, M. 2016. Effect of zinc oxide nanoparticles on the pigment production of clinical isolates of Pseudomonas aeruginos. Sci. J. Ilam Univ. Med. Sci. 5: 1-10

Ojagh, S., Hosseini, H., Ghaemi, E., Irajian, G.H. \& Abdollahzadeh, E. 2018. Quantitative and qualitative evaluation of antibacterial activity of cinnamon essential oil and $\mathrm{znO}$ nanoparticles against listeria. J. Fisheries Sci. Tech. 7:49-55.

Pandurangan, M., Veerappan, M. \& Kim, H. 2015. Cytotoxicity of zinc oxide nanoparticles on antioxidant enzyme activities and mRNA expression in the cocultured C2C12 and 3T3-L1 cells. Appl. Biochem. Biotechnol. 175: 1270-1280.

Ricci, L., Lombardi, D., Pilozzi, E., Biffoni, M., Todaro, M., Peschle, C. \& DeMaria, R. 2007. Identification and expansion of human colon-cancer-initiating cells. Nature 445: 111-115.

Salata, OV. 2004. Application of nanoparticles in biology and medicine. J. Nanobiotechnology. 2: 1-6.

Sharma, N., Sahi, V., Nath, S., Parsons, J., GardeaTorresdey, J. \& Pal, T. 2007. Synthesis of plantmediated gold nanoparticles and catalytic role of biomatrix- embedded nanomaterials. Technol. 41: 5137-5142.

Sun, R., Chen, R., Chung, N., HoC-Lin, C. \& Che, C. 2005. Silver nanoparticles fabricated in Hepes buffer exhibit cytoprotective activities toward HIV- I infected cells. Chem. Commun. 40: 5059-5061.

Sangeetha, G., Rajeshwari, S. \& Venckatesh, R. 2011. Green synthesis of zinc oxide nanoparticles by Aloe barbadensis Miller leaf extract: Structure and optical properties. Materials Res. Bull. 46: 2560-2566.

Singh, R., Shukla, V., Yadav, R., Sharma, P., Singh, P. \& Pandey, A. 2011. Biological approach of zinc oxide nanoparticles formation and its characterization. Adv. Mat. Lett. 2: 313-317.

Stephenson, F.H. 2010. Calculations for molecular biology and biotechnology a guide to mathematics in the laboratory. Second Edition. 13: 45-51.

Thanuja, Y., Pandiyarasan, V., Shanmugapriya, P., Anusuya, T. \& Vairavaraja, P. 2014. Synthesis and characterization of $\mathrm{znO}$ nanoparticles: A green chemistry approach. Asian J. Adv. Basic Sci. 3: 94-101.

Wahab, R., Soon Kim, Y., Mishra, A., Yun, S. \& Shik Shin, H. 2010. Formation of $\mathrm{znO}$ micro-flowers 
prepared via solution process and their antibacterial activity. Nanoscale Res. Lett. 5: 1675-1681

Yang, H., Liu, C., Yang, D., Zhang, H. \& Xi, Z. 2016. Comparative study of cytotoxicity, oxidative stress and genotoxicity induced by four typical nanomaterials: the role of particle size, shape and composition. J. Appl. Toxicol. 29: 69-78.

How to cite this article:

Jangi, M., Mohammadgholi, A. \& Divsalar, A. 2020. The investigation of the effects of synthesized Zinc oxide nanoparticles on the DNA using green chemistry. Nova Biologica Reperta 7: 145-152. (In Persian).

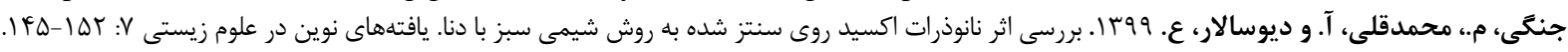

